\title{
ANÁLISE \\ DE ESTRATÉGIAS \\ DE ARGUMENTAÇÃO \\ E POLIDEZ VERBAL \\ NO GÊNERO ENTREVISTA \\ TELEVISIVA
}

\section{ANÁLISIS DE ESTRATEGIAS DE ARGUMENTACIÓN Y CORTESÍA VERBAL EN EL GÉNERO ENTREVISTA TELEVISIVA}

\author{
ANALYSIS OF ARGUMENTATIVE STRATEGIES AND VERBAL POLITENESS IN THE \\ TELEVISION INTERVIEW GENRE
}

\author{
Anaisy Sanches Teixeira* \\ Universidade Estadual de Londrina
}

RESUMO: Este artigo tem por objetivo avaliar as estratégias de argumentação e de polidez verbal envolvidas em uma interação face a face a fim de observar como se relacionam esses procedimentos em um contexto coercitivo aos interagentes, a saber, uma entrevista televisiva de teor político. Efetuaremos esse estudo à luz das teorias da argumentação propostas pela nova retórica de Chaïm Perelman e Lucie Olbrechts-Tyteca (2005) e, no que tange à polidez verbal, nos basearemos em pesquisas de Brown e Levinson (1987), complementadas posteriormente por Kerbrat-Orecchioni (2005), no intuito de melhor compreender como se configura o processo de argumentação e de preservação de face no decorrer da interação. Como procedimentos metodológicos, transcrevermos o corpus selecionado conforme o modelo proposto pelo projeto NURC/SP e realizaremos uma análise qualitativa dos enunciados. PALAVRAS-CHAVE: Pragmática. Análise da conversação. Estratégias de argumentação. Estratégias de polidez verbal.

RESUMEN: Este artículo tiene por objetivo evaluar las estrategias de argumentación y cortesía verbal utilizadas en una interacción cara a cara a fin de observar cómo se relacionan esos procedimientos en un contexto coercitivo para los interlocutores, a saber, una entrevista televisiva de contenido político. Realizaremos este estudio a la luz de las teorías de la argumentación propuestas por la nueva retórica de Chaïm Perelman y Lucie Olbrechts-Tyteca (2005) y, en lo que se refiere a la cortesía verbal, nos basamos en investigaciones de Brown y Levinson (1987), complementadas posteriormente por Kerbrat-Orecchioni (2005), con la finalidad de comprender mejor cómo se configura el proceso de argumentación y preservación de imagen en el transcurso de la interacción.

\footnotetext{
* Instrutora de idiomas no Laboratório de Línguas na Universidade Estadual de Londrina e doutoranda no Programa de Estudos Linguísticos, Literários e
} Tradutológicos em Francês na Universidade de São Paulo. E-mail: anaisyy@gmail.com. 
Como procedimientos metodológicos, transcribimos el corpus seleccionado según el modelo propuesto por el proyecto NURC / SP y realizaremos un análisis cualitativo de los enunciados.

PALABRAS CLAVE: Pragmática. Análisis de la conversación. Estrategias de argumentación. Estrategias de cortesía verbal.

ABSTRACT: This article aims to evaluate the strategies of verbal politeness and argumentation involved in a face-to-face interaction in order to observe how these procedures are related in a context that turns out to be coercive to the interacting agents, namely a televised political interview. We will carry out this study according to the theories of argumentarion proposed by the new rhetoric of Chaïm Perelman and Lucie Olbrechts-Tyteca (2005) and, as far as verbal politeness is concerned, it will be based on Brown and Levinson (1987) complemented later by Kerbrat-Orecchioni (2005), in order to better understand how the process of argumentation and face saving is configured during the interaction. As methodological procedures, we transcribe the selected corpus according to the model proposed by the NURC / SP project and perform a qualitative analysis of the statements.

KEYWORDS: Pragmatic. Conversation analysis. Argument strategies. Verbal politeness strategies.

\section{INTRODUÇÃO}

Ao interagir, os participantes de uma situação comunicativa colocam em prática uma série de regras linguageiras às quais todos devem se engajar para que o objetivo comunicativo da interação se cumpra de modo relativamente harmonioso, sobretudo em contextos conflituosos.

Como as interações verbais são co-produzidas e resultantes de um intenso trabalho colaborativo, pode-se dizer que negociar é algo inerente a todo processo interacional, especialmente em situações que envolvam interesses pessoais ou institucionais, como no contexto político. Nesse sentido, os interlocutores, ao buscarem a aceitação de suas ideias, acionam uma série de procedimentos de negociação, tais como estratégias de argumentação e de polidez verbal, no decorrer de uma interação.

Isto posto, este artigo tem por objetivo analisar a natureza desses procedimentos e verificar como se relacionam em um contexto coercitivo, a saber, em uma entrevista televisiva, em que os interagentes, ao mesmo tempo que devem cumprir seu papel comunicacional, ou seja, questionar e responder, também devem convencer os participantes e telespectadores da pertinência de seus argumentos, além de proteger sua face e identidade a fim de construir uma imagem positiva perante à sociedade.

Nossa proposta consiste em observar como essas estratégias funcionam, principalmente as de natureza verbal, e em que medida determinam a evolução da interação. Os mecanismos paraverbais ou não-verbais também poderão ser considerados nesse estudo a depender de sua influência no desenvolvimento do discurso.

Para fundamentar nossa análise, no que se refere às estratégias de argumentação, nos basearemos em estudos desenvolvidos por Chaïm Perelman e Lucie Olbrechts-Tyteca (2005) na obra O tratado da argumentação: a nova retórica, responsável por ampliar de modo significativo o conhecimento acerca do discurso argumentativo. Em relação aos mecanismos de polidez verbal, nos apoiaremos nos trabalhos de Brown e Levinson (1987), complementados posteriormente por Kerbrat-Orecchioni (2005).

Dentre as diversas situações de fala, elegemos uma entrevista televisiva proveniente do programa semanal Roda Viva, veiculado em 2005 pela TV Cultura de São Paulo, que recebeu, na ocasião, o então presidente da República Luiz Inácio Lula da Silva, doravante Lula.

Apesar de apresentarem certo grau de planejamento, no ato de sua execução, as entrevistas adquirem um caráter de imprevisibilidade, o que as transforma em objetos de observação relevantes para a compreensão do processo interacional que será examinado. 


\section{FUNDAMENTAÇÃO TEÓRICA}

O suporte teórico que embasa o presente estudo está pautado em teorias da Retórica e da Pragmática. Ainda que tenham se desenvolvido em momentos díspares, ambas apresentam similitudes em relação a como compreendem o discurso.

Assim como a Pragmática, que visa à utilização da linguagem por um enunciador dirigindo-se a um alocutário em um contexto determinado, a Retórica antiga se preocupava com o estudo da força persuasiva do discurso proferido por um orador endereçandose a um auditório, bem como com questões relativas à eficácia do discurso considerado a partir de seu contexto de produção, fato que leva alguns estudiosos a definir a Pragmática como a Retórica dos antigos. Dominique Maingueneau (1998, p. 66) afirma que "[...] ela veio, de certa maneira, substituir a retórica tradicional". Nessa perspectiva, por ter resgatado os estudos retóricos de Aristóteles, Perelman (2005) é considerado, por alguns autores, como o precursor da Pragmática.

Ainda que alguns teóricos façam distinção entre os termos retórica e argumentação, compreendemos, habitualmente, a retórica como uma disciplina genérica que engloba a argumentação. Dessa forma nos basearemos em Perelman e Obrechts-Tyteca (2005) que não os distinguem, como o próprio nome de sua obra indica - "Tratado da Argumentação: a nova retórica”.

\subsection{A NOVA RETÓRICA: ESTRATÉGIAS DE ARGUMENTAÇ̃̃O}

A argumentação é objeto de investigação desde a civilização greco-romana e no decorrer da história, passou por períodos de prestígio e de descrédito, até conhecer um renascimento importante na época contemporânea.

Segundo Plantin (2009, p. 13)

[...] os estudos de argumentação têm sua origem em três disciplinas clássicas: a retórica, a lógica e a dialética. Elas constituem um fundo sempre estimulante para a reflexão, já que o desenvolvimento das competências linguísticas que elas propõem a organizar - falar bem, raciocinar bem e dialogar bem - não perderam sua atualidade.

Conforme os objetivos desta pesquisa, elegemos a nova retórica de Perelman e Olbrechts- Tyteca (2005), que reata a tradição retórica aristotélica e a atualiza, para conduzir nossa análise.

Aristóteles (1998) foi o primeiro autor a expor uma concepção sistemática da argumentação, concebendo, inicialmente, a teoria do raciocínio dialético e dedicando-se, posteriormente, a aspectos relativos à persuasão do auditório. Segundo o filósofo (ARISTÓTELES, 1998), a argumentação seria a associação de um processo racional e social. Assim como defendia Aristóteles, Perelman e Olbrechts-Tyteca (2005) afirmam que

[...] quando se trata de argumentar, de influenciar, por meio do discurso, a intensidade de adesão de um auditório a certas teses, já não é possível menosprezar completamente, considerando-as irrelevantes, as condições psíquicas e sociais sem as quais a argumentação ficaria sem objeto ou sem efeito, pois toda argumentação visa à adesão dos espíritos e, por isso mesmo, pressupõe a existência de um contato intelectual. (PERELMAN; OlBRECHTS-TYTECA, 2005, p. 16)

Os autores definem a argumentação como o "[...] estudo das técnicas discursivas que permitem provocar ou aumentar a adesão dos espiritos às teses que se lhes apresentam ao assentimento" (PERELMAN; OLBRECHTS-TYTECA, 2005, p. 04).

A partir dessas asserções, pode-se observar que Perelman (2005) interessa-se permanentemente pela questão do auditório, quer como fonte de opinião, quer como seu destinatário. O autor considera que uma condição prévia de qualquer argumentação eficaz é conhecer as pessoas que se deseja conquistar, desvelando a cultura própria de cada auditório e definindo a melhor forma de recepção dos argumentos. Apesar de se opor à atribuição de uma importância excessiva a uma tipologia dos argumentos, termina por elaborar uma teoria em que propõe uma série de definições sobre esse tópico. Distingue, então, quatro grandes técnicas

Forum lingüístic., Florianópolis, v.15,n.3,p.3192-3209,jul./set. 2018 
argumentativas: os argumentos quase-lógicos, os argumentos baseados na estrutura do real, as ligações que fundamentam a estrutura do real e a dissociação das noções.

Os argumentos quase-lógicos são construídos com base no modelo do raciocínio lógico ou matemático enquanto que os argumentos baseados na estrutura do real, bem como as ligações que fundamentam a estrutura do real, são técnicas de ligação. No primeiro caso, a ligação já existe no real, ou seja, são argumentos formulados a partir de um elemento já aceito pelo auditório para introduzir outros que se querem ver admitidos, ao passo que, no segundo caso, são concebidos por inferências e fundam generalizações procurando estabelecer regras e princípios a partir de casos isolados e se subdividem em fundamento pelo caso particular e raciocínio por analogia. O autor distingue duas grandes categorias de argumentos baseados na estrutura do real: a ligação de sucessão, como a relação de causa e efeito, e a ligação de coexistência, que implica uma relação entre realidades de nível desigual, como por exemplo, a pessoa, suas ações, opiniões ou obras. Por fim, a dissociação das noções refere-se a argumentos que dissociam elementos inicialmente considerados como fazendo parte de um todo.

A título de ilustração, apresentaremos uma tabela ${ }^{1}$ composta pelas quatro categorias de técnicas argumentativas acompanhadas por suas respectivas modalidades.

Tabela 1: Tipos de argumentos e suas modalidades segundo a nova retórica de Perelman e Olbrechts- Tyteca (2005).

\begin{tabular}{|c|c|c|c|}
\hline \multirow[b]{2}{*}{$\begin{array}{l}\text { ARGUMENTOS QUASE } \\
\text { LÓGICOS }\end{array}$} & \multicolumn{2}{|c|}{ LIGAÇÕES } & \multirow[b]{2}{*}{$\begin{array}{c}\text { DISSOCIAÇÃO } \\
\text { DAS NOÇÕES }\end{array}$} \\
\hline & $\begin{array}{l}\text { Argumentos baseados na } \\
\text { estrutura do real }\end{array}$ & $\begin{array}{c}\text { Ligações que fundamentam a } \\
\text { estrutura do real }\end{array}$ & \\
\hline $\begin{array}{c}\text { - Contradição e } \\
\text { incompatibilidade } \\
\text { - Identidade e definição } \\
\text { - Analiticidade, análise e } \\
\text { tautologia } \\
\text { - Regra de justiça } \\
\text { - Argumentos de } \\
\text { reciprocidade } \\
\text { - Argumentos de } \\
\text { transitividade } \\
\text { - Inclusão da parte no todo } \\
\text { - Divisão do todo em suas } \\
\text { partes } \\
\text { - Argumentos de comparação }\end{array}$ & $\begin{array}{c}\text { as ligações de sucessão: } \\
\text { - Vínculo causal e } \\
\text { argumentação } \\
\text { - Argumento pragmático } \\
\text { - Fins e meios } \\
\text { - Argumento do desperdício } \\
\text { - Argumento da direção } \\
\text { - Superação } \\
\text { b) as ligações de coexistência: } \\
\text { - Pessoa e seus atos } \\
\text { - Interação entre ato e pessoa } \\
\text { Argumento de autoridade } \\
\text { - Técnicas de ruptura e de } \\
\text { refreamento } \\
\text { - Discurso como ato do orador } \\
\text { - Grupo e seus membros } \\
\text { - Ato e essência } \\
\text { - Ligação simbólica } \\
\text { - Argumento de hierarquia } \\
\text { - Argumentos de diferenças de } \\
\text { grau e ordem }\end{array}$ & $\begin{array}{l}\text { a) o fundamento pelo caso } \\
\text { particular: } \\
\text { - Argumentação pelo exemplo } \\
\text { - Ilustração } \\
\text {-Modelo e antimodelo } \\
\text { b) o raciocínio por analogia: } \\
\text { - Analogia } \\
\text { - Metáfora }\end{array}$ & $\begin{array}{c}\text { - Ruptura de ligação e } \\
\text { dissociação } \\
\text { - Par “aparência-realidade" } \\
\text { - Pares filosóficos e justificação } \\
\text { - Retórica como expediente }\end{array}$ \\
\hline
\end{tabular}

Fonte: autoria própria

\footnotetext{
${ }^{1} \mathrm{O}$ objetivo da tabela é ilustrar as modalidades de técnicas argumentativas estabelecidas por Perelman e Olbrechts-Tyteca (1996). Por uma questão de limites, somente os argumentos que se apresentarem no corpus serão conceituados no decorrer da análise.
} 
Como este trabalho objetiva, além da observação do emprego de estratégias de argumentação em contexto coercitivo, analisar como se comportam os mecanismos de polidez verbal, passaremos, a seguir, à exposição dessa teoria.

\subsection{A POLIDEZ VERBAL}

Por volta dos anos 70 surgiram os primeiros estudos sobre a polidez graças a pesquisadores como R. Lakoff (1975), G. Leech (1983) e, sobretudo, P. Brown e S. Levinson (1987 [1978]). A teoria proposta por Brown e Levinson tem sido a mais célebre e elaborada no que tange ao estudo dos fenômenos verbais da polidez.

Brown e Levinson (1987 [1978]) baseando-se na noção de face introduzida por Goffman (1974), estabelecem o conceito de face e o ampliam ao introduzir ao seu lado a noção de território. Ambas as denominações foram rebatizadas de face positiva e face negativa. A face positiva corresponde à imagem de si e ao desejo de ser aceito, reconhecido e valorizado pelo outro. Seria a necessidade de aprovação social. A face negativa refere-se à zona de liberdade de ação do eu no interior da qual os indivíduos têm o direito de agir conforme seus desejos. Consequentemente, em toda interação há, ao menos, quatro faces envolvidas: a positiva e a negativa do locutor e do interlocutor.

Dessa forma, o indivíduo, ao interagir, deve preservar sua face, assim como a de seu interlocutor. Todavia, grande parte dos atos empregados em uma interação representa uma ameaça às faces envolvidas nesse processo. Brown e Levinson (1987 [1978]), para designar esses atos ameaçadores, criam a noção de Face Threatening Act (FTAs).

Kerbrat-Orecchioni (2005, p. 79) apresenta uma síntese dos FTAs e os divide em quatro categorias:

- atos ameaçadores da face positiva do interlocutor: colocam em risco a autoestima do outro;

- atos ameaçadores da face negativa do interlocutor: violações territoriais de natureza verbal e não-verbal;

- atos ameaçadores da face positiva do locutor: comportamentos autodegradantes;

- atos ameaçadores da face negativa do locutor: atingem o território daquele que os realiza, algo que propõe efetuar e que é suscetível de lesá-lo.

A autora, baseando-se principalmente no modelo de Brown e Levinson (1987 [1978]), propõe um sistema de polidez verbal mais coerente, articulado e universal se comparado aos estudos de seus fundadores e defende que as representações da interação por eles desenvolvidas enfatizam, essencialmente, seu caráter ameaçador. Conforme destaca Kerbrat-Orecchioni esse modelo apresenta "[...] uma concepção excessivamente pessimista, e até mesmo 'paranoide', da interação - representando os indivíduos em sociedade como seres vivos sob ameaça permanente de FTAs de todo gênero, e passando seu tempo a montar guarda em torno de seu território e de sua face" (KERBRAT-ORECCHIONI, 2005, p. 81).

Assim, Kerbrat-Orecchioni (2005) observou que alguns atos são mais lisonjeadores que ameaçadores e, em complementação aos FTAs introduzidos por seus antecessores, criou os FFAs - Face Flattering Acts - atos lisonjeadores, ou seja, todo aquele que provoca efeito positivo na face dos participantes da interação, por exemplo, elogios e agradecimentos. A contribuição da estudiosa permitiu a formação de dois grupos: polidez negativa, de natureza abstencionista ou compensatória, em que o indivíduo evita cometer atos ameaçadores e procura reparar os que já cometeu, e polidez positiva, de natureza produtiva, em que o indivíduo produz atos lisonjeadores.

Enquanto a polidez positiva consiste simplesmente em produzir atos que tenham caráter antiameaçador ao destinatário (agradecimentos, elogios, manifestação de concordância, etc.), a polidez negativa consiste em evitar que um ato lhe seja ameaçador ou em procurar suavizar os efeitos dos FTAs a eles dirigidos recorrendo a procedimentos que Brown e Levinson (1987 [1978]) denominam atenuadores (softeners). A atenuação, portanto, diminui a força ilocutória de um enunciado a fim de preservar a face do destinatário e pode ser de natureza paraverbal (tom da voz, marcas de hesitação, etc.), não verbal (sorriso, inclinação da cabeça, etc.) e verbal, estratégia que nos interessa especificamente. Os atenuadores verbais podem ser substitutivos - quando substituem o 
ato ameaçador por uma formulação suavizada - ou subsidiários - acompanham-no com uma partícula minimizadora de possíveis resultados negativos.

Segundo Kerbrat-Orecchioni (2005, p. 86-87) os principais procedimentos substitutivos classificam-se em: atos de linguagem indiretos, desatualizadores modais, temporais e pessoais, pronomes pessoais, figuras de estilo (lítotes ou eufemismo) e tropo comunicacional. Em relação aos procedimentos subsidiários, a autora (2005) destaca as fórmulas de polidez, os enunciados preliminares, os procedimentos reparadores, os desarmadores, apaziguadores, modalizadores e minimizadores.

Além das estratégias de polidez mencionadas, Kerbrat-Orecchioni (2014, p. 53) também propõe os conceitos de hiperpolidez, presença no enunciado de marcadores excessivos em relação às normas em vigor, não-polidez ou apolidez, ausência "normal" de qualquer marcador de polidez acompanhado de um FTA, e impolidez, ausência de um marcador de polidez esperado, em caso de impolidez negativa, bem como a presença de um marcador de impolidez, em caso de impolidez positiva.

Objetivamos, portanto, verificar o papel dessas estratégias ao serem empregadas em interações de teor argumentativo. Passaremos, a seguir, à exposição dos procedimentos metodológicos e, posteriormente, à análise dos dados.

\section{METODOLOGIA}

Com o objetivo de analisar a tipologia das estratégias de argumentação e de polidez verbal em uma interação face a face, selecionamos uma entrevista proveniente do programa Roda Viva da TV Cultura que, em 2005, recebeu o ex-presidente Lula, que se encontrava em seu terceiro ano de mandato e vivenciava uma das maiores crises políticas da história brasileira deflagrada pela suspeita de um esquema de corrupção no Congresso Nacional, convencionalmente chamada de "mensalão". Apesar de ser um excerto, trata-se de uma sequência ininterrupta que transmite os dez minutos iniciais da entrevista e tem como fonte direta a imprensa eletrônica (site da internet).

A entrevista em questão apresenta um caráter excepcional em termos organizacionais. Por ocasião da comemoração de sua milésima edição do programa, a entrevista com Lula ocorreu nas dependências do Palácio do Planalto. A programação perdeu, portanto, sua configuração espacial habitual, o que contribuiu para a formação de um cenário menos intimidador: os entrevistadores se dividiram em dois grupos, um do lado esquerdo e outro do direito, e se acomodaram frente ao presidente sentado em uma confortável poltrona. Além disso, a transmissão ao vivo foi substituída por uma gravação.

A entrevista foi dirigida e mediada por Paulo Markun, apresentador, jornalista e historiador, que estava acompanhado de outros cinco entrevistadores. Participam especificamente do excerto, além de Markun, Augusto Nunes e Heródoto Barbeiro, titulares do programa, e os jornalistas convidados Roseli Tardeli e Rodolfo Konder.

O método que adotamos para nossa análise é de natureza qualitativa e não possui qualquer pretensão à exaustão. Por ser um trabalho de observação detalhada das interações, o corpus foi integralmente transcrito conforme as normas propostas pelo projeto NURC/SP.

\section{ANÁLISE DOS DADOS}

A entrevista analisada tem início em tom harmonioso, até mesmo descontraído, uma vez que entrevistador e entrevistado trocam saudações e agradecimentos. Por sinal, é a única ocorrência de FFAs, conforme postula Kerbrat-Orecchioni (2005), presente entre os interactantes. Paulo Markun dirige-se ao entrevistado empregando o pronome "senhor", acompanhado pela forma de tratamento "presidente", escolha que perdurará no decorrer de todo o excerto e que será igualmente adotada por cada um dos participantes, pois, hierarquicamente falando, na ocasião, Lula era o símbolo do mais alto poder político do país. Trata-se, pois, de uma interação

Teixeira Análise de estratégias de argumentação e polidez verbal no gênero entrevista televisiva 
assimétrica em que a posição superior do entrevistado provoca a deferência dos demais interactantes. Tanto que o presidente dirigese a seu interlocutor de modo menos formal, "Markun".

\section{FRAGMENTO $1^{23}$}

\begin{tabular}{|c|c|c|}
\hline MARKUN & 01 & boa noite... presiDENte ${ }^{2}$ \\
\hline LULA & 02 & boa noite... \\
\hline MARKUN & 03 & obrigado pela presença do senhor... aqui \\
\hline LULA & $\begin{array}{l}04 \\
05 \\
06 \\
07 \\
08 \\
09 \\
10 \\
11\end{array}$ & $\begin{array}{l}\text { Markun... eu é que devo agradecer... porque.. é uma honra participar do Roda } \\
\text { Viva... quando está comemorando seu miLE }{ }^{3} \text { simo programa... e:..... no ano em que se } \\
\text { comemora:.... trinta anos... da morte do Vlado... que era diretor da TV CulTUra } \\
\text { quando fizeram a primeira entrevista comigo... não deu para vocês perceBErem... } \\
\text { mas:.... as minhas pernas estavam tremendo... porque quando acenderam a LUZ e } \\
\text { colocaram o microfone na minha fren::te... quase que eu desmaio ali... mas... de } \\
\text { qualquer forma... é uma aleGRIa poder estar participando com VOCES do Roda } \\
\text { Viva... nesse momento hisTÓrico do Roda Viva... }\end{array}$ \\
\hline
\end{tabular}

No fragmento 2, logo ao fazer a primeira pergunta, talvez por prever os riscos aos quais submeteria a face do entrevistado devido à delicadeza do questionamento colocado, o entrevistador utiliza várias estratégias de polidez negativa. Além do emprego de três sequências de enunciados preliminares (linhas 13, 16 e 21), lança mão do modalizador "eu creio que" (linha 15), bem como dos desatualizadores pessoais “uma pessoa”, "o presidente de república” (linhas 17 e 23), além do uso dos agentes inanimados "denúncias que se apresentaram" (linhas 18 e 19), "fatos que escandalizaram" (linha 24) e do desatualizador temporal "tem dito" (linha 19 e 20), conferindo à pergunta um caráter menos contundente. Como se trata do início da interação, momento em que as relações ainda estão sendo estabelecidas, não foram observadas ocorrências de estratégias de argumentação.

\section{FRAGMENTO 2}

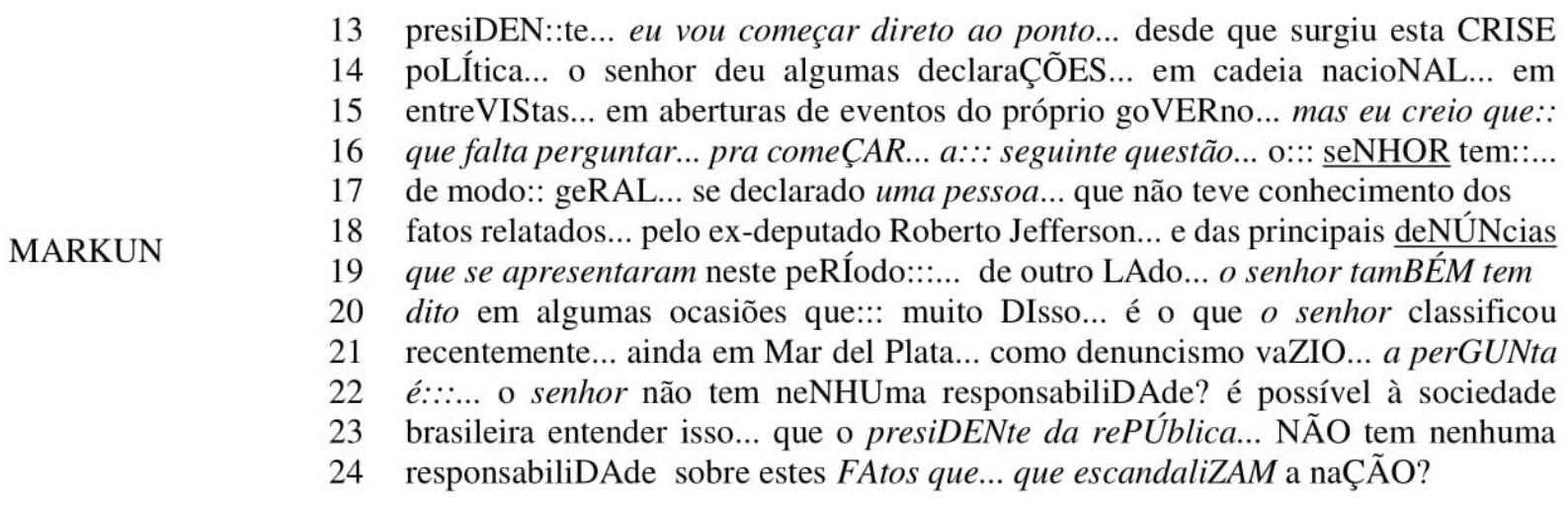

No trecho subsequente, julgamos pertinente observar como Lula, ao iniciar sua resposta, recupera o desatualizador pessoal "o presidente da república" introduzido pelo entrevistador e constrói seu discurso argumentativo de forma mais distanciada, encobrindo a opinião pessoal sob a autoridade do presidente (linhas 25, 26 e 27). Ao mesmo tempo que desatualiza o sujeito, inicia sua argumentação recuperando os deveres de um presidente ao explorar a estratégia argumentativa de natureza quase-lógica identidade e definição (linhas 25-29). Dentre os procedimentos de identificação, Perelman e Olbrechts-Tyteca (2005, p. 238) distinguem "[...] aqueles que visam a uma identidade completa e outros que não pretendem mais do que uma identidade parcial dos elementos confrontados". Segundo os autores, o procedimento mais característico de identificação completa consiste no uso de definições. Perelman e Olbrechts-Tyteca (Ibid., p. 239) distinguem ainda, juntamente com Arne Naess, quatro espécies de definição, dentre elas, as definições normativas, "[...] que indicam a forma em que se quer que uma palavra seja utilizada. Tal norma pode

\footnotetext{
${ }^{2}$ As ocorrências de polidez verbal serão destacadas em itálico, enquanto que as estratégias de argumentação serão destacadas em negrito.

${ }^{3}$ As letras maiúsculas referem-se à entoação enfática, conforme as normas de transcrição do projeto NURC/SP.
} 
resultar de um compromisso individual, de uma ordem destinada a outros, de uma regra que se crê que deveria ser seguida por todos"4, contexto em que, de acordo com nossa intepretação, se insere a estratégia argumentativa apresentada pelo entrevistado.

\section{FRAGMENTO 3}

LULA

25 NÃO... primeiro... o presiDENte da rePÚ::blica... tem TOda a responsabiliDAde...

26 ou seja... pe/ pelo bem ou pelo MAL::... não tem COMO o presidente da

27 república dizer que:: não tem responsabiliDAde... sabendo ou não saBENdo... $o$

28 presidente da rePÚblica... tem que TER responsabilidade e tem que MANDAR

29 APURAR... este é o paPEL do presidente da república... uma coisa... que eu acho...

30 extremaMENte GRAve é que ninGUÉM traz na testa... escrito... "eu vou praticar um

31 ato ilícito... eu vou fazer corrupção"... porque quando o o:: deputado Roberto

32 Jefferson fez a denúncia... ele foi cassado exatamente... porque:: não provou as

33 denúncias que ele FEZ... no que diz respeito... por exemplo... aos mensalões... o

34 que ele provou... é que o PT teve uma PRÁtica de financiaMENto de campanha...

35 totalmente contra a história do PRÓprio partido... e isso está sendo apurado na

36 CPI...

Ao sustentar sua argumentação, Lula faz uso do modalizador “eu acho" (linha 29) para apresentar uma espécie de justificativa que diminuiria, a priori, sua responsabilidade em relação aos acontecimentos: “uma coisa que 'eu acho’ extremamente grave é que ninguém traz na testa... escrito... eu vou praticar um ato ilícito... eu vou fazer corrupção"; empregando, assim, os desatualizadores pessoais "uma coisa" e "ninguém", bem como o eufemismo "ato ilícito". Ele recupera, em seguida, o fato central que desencadeou todo o processo investigativo do mensalão, a denúncia do deputado Roberto Jefferson, estabelecendo uma ligação causal entre o fato de ele ter sido cassado - conjugado, a propósito, na voz passiva (linha 32) - por não ter provado as denúncias que fez. Explora, desse modo, o argumento baseado na estrutura do real vínculo causal, bem como a regra de justiça, segundo a qual os "seres de uma mesma categoria essencial devem ser tratados do mesmo modo" (PERELMAN; OLBRECHTS-TYTECA, 2005, p. 248).

Logo depois, o entrevistado atenua o envolvimento do "PT", desatualizador pessoal, ao dizer que a única prova que o deputado apresentou diz respeito a uma "prática de financiamento de campanha... totalmente contra a história do próprio partido", denúncia que, segundo Lula, ainda não se confirmou, uma vez que está em processo de apuração na CPI.

Pode-se observar, nesse excerto, que no desenrolar de todo o movimento argumentativo desenvolvido pelo presidente, há a presença de mecanismos de polidez verbal que atenuam o impacto de suas colocações.

O titular Augusto Nunes, ao fazer sua primeira pergunta, assim como o entrevistador precedente, utiliza mecanismos de polidez verbal para se dirigir ao entrevistado. Emprega as formas de tratamento "presidente" (linha 37) e "senhor" (linhas 39, 42, 43 e 44), este último reiteradamente, sobretudo no final da pergunta, em que apresenta algumas situações que fazem apelo a uma suposta reação emocional do presidente frente a possíveis irregularidades no Congresso, o que iria de encontro ao que se espera de alguém que ocupa o maior cargo político do país, e que denota, dessa forma, um ataque à face do político. Ainda, para atenuar sua pergunta, emprega o desatualizador pessoal "Brasil", os enunciados preliminares "uma dúvida aqui", "é a seguinte” (linhas 37 e 38 ), o eufemismo "irregularidades" (linha 42) e uma série de desatualizadores temporais (linha 38), como o futuro do pretérito composto (linhas 39, 40, e 43) e o mais-que-perfeito (linha 44), conferindo maior sutileza ao enunciado. 


\section{FRAGMENTO 4}

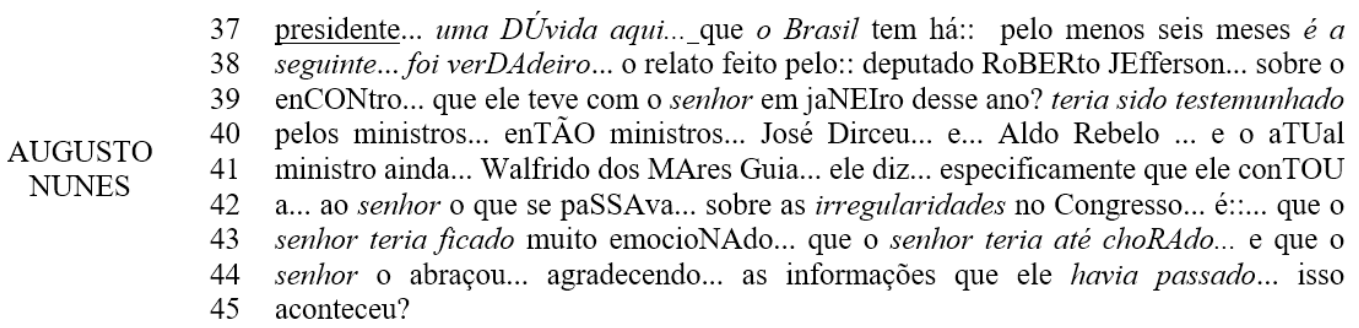

No fragmento 5, o então presidente Lula inicia sua fala elencando quais seriam as reais testemunhas do ocorrido, explicitando, em alguns casos, os cargos que ocupavam, a saber, Walfrido dos Mares Guia e Arlindo Chinaglia, buscando, talvez, dar maior legitimidade e confiabilidade a seu discurso, uma vez que líderes importantes do governo poderiam assegurar o que afirma o presidente. Essa estratégia argumentativa é denominada por Perelman e Olbrechts-Tyteca (2005) como argumento de autoridade.

\section{FRAGMENTO 5}

51 aconteceu sem a presença do Zé Dirceu... aconteceu na presença do Walfrido dos

52 Mares Guia ... aconteceu na presença do líder do PTB::... e do Líder do governo...

53 ATUAL líder... Arlindo Chinaglia... ORA... na medida que há:: essa essa

54 insinuação.... ou essa afirmação de $\mathrm{um}$ depuTAdo ... o que é que eu fiz? nós

55 tínhamos o:: Aldo Rebelo como líder do governo no ConGREsso... nós tínhamos o

LULA 56 Arlindo Chinaglia... como líder do:::: como como:: como líder DO PT... e EU...

57 peDI aos dois que explicassem se era verdade... ELES... CATEGORICAMENTE...

58 disseram que isso... era uma peça de ficção que não existia mensalão... dentro do

59 Congresso Nacional... e:: pelo que consta até aGOra... ATÉ AGORA... não foi...

60 provado que tem mensalão... tem quinhentos e treze deputados... ATÉ agora... $o$

61 que FOI CASSADO... foi cassado porque... contou uma inverdade sobre o

62 Congresso Nacional...

Em seguida, Lula estabelece um vínculo causal entre uma "insinuação" ou "afirmação" de "um" deputado - desatualizador pessoal e o pedido de esclarecimentos feito aos representantes Aldo Rebelo, líder do governo no Congresso e, mais uma vez, a Arlindo Chinaglia, líder do PT, que disseram "categoricamente" que "isso era uma peça de ficção", que "não existia mensalão dentro do Congresso Nacional”. O recurso ao argumento de autoridade é, novamente, solicitado e ainda mais intensificado quando Lula cita os "quinhentos e treze deputados" que não provaram a existência do mensalão, sendo que o único que o fizera, "foi cassado porque contou uma inverdade sobre o Congresso Nacional”. Ao realizar essa afirmação, Lula repete o uso da estratégia de vínculo causal que se combina com o eufemismo "uma inverdade”, mecanismo de polidez verbal. Além disso, nessa passagem, também desatualiza o sujeito e emprega a voz passiva, "o [deputado] que foi cassado", utilizando mais uma estratégia de polidez negativa (linhas 61 e 62).

Outro dado importante na construção argumentativa de Lula e que se entrelaça com o âmbito da polidez verbal é o uso dos pronomes pessoais que variam entre "eu" (linhas 54 e 56) e "nós" (linhas 54 e 55), o que constrói um movimento argumentativo que ora representa o presidente, ora o partido do qual faz parte. Desse modo, forma-se a seguinte configuração: de um lado, temos o presidente, o seu partido e mais quinhentos e treze deputados, e de outro, o deputado que foi cassado porque contou uma inverdade sobre o Congresso Nacional. Configura-se aí, segundo Perelman e Olbrechts-Tyteca (2005), o argumento baseado na estrutura do real o grupo e seus membros. De acordo com os autores (OLBRECHTS-TYTECA, 2005, p. 368), "[...] a interação entre o indivíduo e o grupo pode ser utilizada para valorizar ou desvalorizar seja um, seja o outro". Além disso, destacam que "[...] a única técnica que permite realizar uma ruptura de interação entre grupo e indivíduo é a da exclusão deste: poderá ser aplicada quer pelo próprio indivíduo, quer pelos outros membros do grupo, quer por terceiros” (OLBRECHTS-TYTECA, 2005, p. 369).

Acreditamos também que o desfecho desse fragmento, "a cassação de Roberto Jefferson", talvez sirva como uma espécie de exemplo aos demais deputados. Essa tática argumentativa, segundo Perelman e Olbrechts-Tyteca (2005), consiste em partir de casos concretos para proceder a generalizações. Outro dado que julgamos pertinente ressaltar nesse fragmento refere-se às escolhas

Forum lingüístic., Florianópolis, v.15,n.3,p.3192-3209, jul./set. 2018 
lexicais que remetem à palavra mensalão em que dois termos - insinuação e peça de ficção - reforçam a ideia de algo irreal, imaginário, inventado, contra um único termo de caráter assertivo - afirmação.

No excerto subsequente, podemos notar que a fala de Lula está repleta de "modalizadores verbais" (linhas 67, 70 e 73), estratégia de polidez verbal que assinala que a opinião exposta deve ser tratada a partir de um viés pessoal, oferecendo um caráter menos definitivo ao enunciado, de modo a dar mais liberdade ao interlocutor. Em termos de polidez, há ainda o emprego da voz passiva "foi cassado" (linha 78), do desatualizador temporal “tenha existido’ (linha 68), da expressão hipotética "pode ser” (linha 69), dos eufemismos "envolvimento" (linha 70) e "desserviço" (p. 74), que suavizam as declarações feitas pelo presidente, e ainda, a variação no uso dos pronomes pessoais "eu”, "a gente" e "nós" (linhas 70, 71, 74 e 75), que implicam o locutor com maior ou menor intensidade no discurso em termos estratégicos.

\section{FRAGMENTO 6}

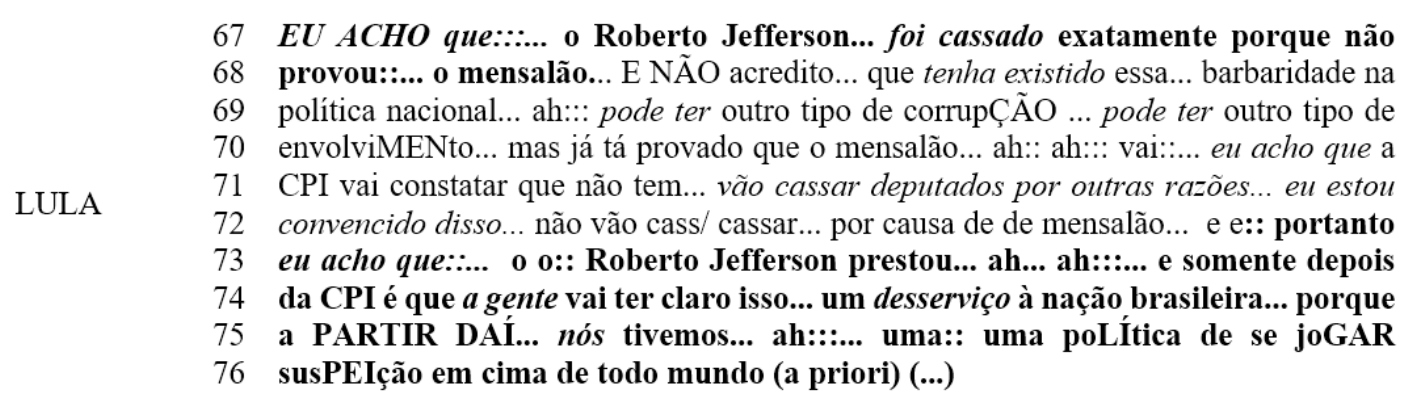

Em relação ao emprego de estratégias de argumentação, visto que esse fragmento seria uma espécie de extensão do anterior, logo de início, há o emprego da mesma vinculação causal (linha 67 e 68) efetuada no excerto precedente, o que a reforça. Em seguida, o entrevistado apresenta sua visão sobre os fatos, em que menciona não acreditar que "essa barbaridade" tenha ocorrido na política nacional e encerra seu raciocínio fazendo uso de um argumento pragmático (linhas 73-76) ao dizer que, a consequência da atitude do deputado Roberto Jefferson foi “jogar suspeição em cima de todo mundo”. Nas palavras de Perelman e Olbrechts-Tyteca (2005, p. 303), o argumento pragmático é "[...] aquele que permite apreciar um ato ou um acontecimento consoante suas consequências favoráveis ou desfavoráveis”. Dessa forma, podemos notar que, novamente, argumentação e polidez se entrelaçam.

Outro ponto que acreditamos relevante refere-se ao momento em que Lula afirma "vão cassar deputados por outras razões... eu estou convencido disso" (linha 71 e 72). Apesar de, aparentemente, endereçar-se aos entrevistadores, talvez o entrevistado tenha outro alvo como destinatário pretendido, por exemplo, a classe política. Essa estratégia de polidez negativa, denominada tropo comunicacional, implica uma inversão na hierarquia normal dos destinatários. Esse tom misterioso é reforçado pela desatualização do sujeito.

No próximo trecho, o titular Heródoto Barbeiro tenta vincular o deputado Roberto Jefferson, delator do mensalão que fazia parte da base aliada do governo, ao grupo de Lula, movimento que se opõe absolutamente à estratégia argumentativa do ex-presidente, que buscava desvincular a imagem do deputado à de seu grupo político. Já ciente de que seria um ataque à face de seu interlocutor, o entrevistador, além de fazer sua pergunta na forma negativa (linha 77), estratégia que se repete na linha 79, emprega a voz passiva (linha 77) e, em ambas as linhas, faz uso de um desatualizador temporal. Apesar das perguntas elaboradas na forma negativa não fazerem parte da classificação proposta por Kerbrat-Orecchioni (2005), acreditamos que se trata de uma estratégia de polidez verbal que visa a proteger a face do interlocutor pelo fato de se empregar uma negação em vez de uma asserção. 


\section{FRAGMENTO 7}

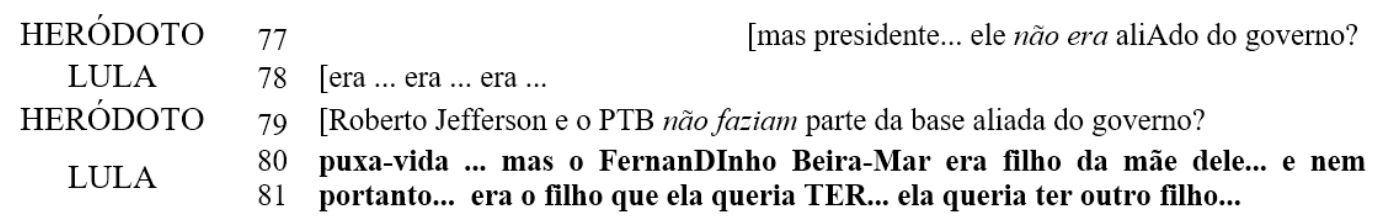

Lula, aparentemente indignado, deixa escapar um "puxa-vida" e se defende empregando uma analogia (linhas 80 e 81 ) que envolve Fernandinho Beira-Mar, um dos maiores criminosos do país. A analogia, segundo Breton (2001, p. 69), parafraseando Perelman e Olbrechts-Tyteca (2005), trata-se do "[...] estabelecimento de uma relação entre o que se pretende argumentar (o que se chama "tema") e um elemento que se vai procurar noutra zona do real ("o foro") e que já é aceite pelo auditório (está-se sempre à procura do acordo prévio)".

O titular Augusto Nunes assalta o turno do entrevistado e menciona um fato controverso relativo a uma suposta oferta de um cheque em branco a Roberto Jefferson efetuada por Lula. Prontamente, o ex-presidente se defende lançando mão do artifício de polidez lítotes "não é verdade" (linha 84). Como o entrevistador insiste em sua afirmação, Lula reitera veementemente que "não declarou" nada na saída do jantar (linhas 86 e 87) e, em seguida, faz uso da estratégia argumentativa a interação entre o ato e a pessoa, dizendo ao jornalista: "você sabe que eu não sou de declarar". De acordo com Perelman e Olbrechts-Tyteca (2005, p. 338) “[...] um ato é, mais do que um indício, um elemento que permite construir e reconstruir nossa imagem da pessoa [...]”. Os autores (OLBRECHTS-TYTECA, 2005, p. 339) afirmam também que ato “[...] é tudo quanto pode ser considerado emanação da pessoa, sejam eles ações, modos de expressão, reações emotivas, cacoetes involuntários ou juízos”. Desse modo, Lula reivindica uma imagem positiva que julga ter perante seu interlocutor, pré-definida a partir de um conjunto de experiências anteriores. Inicia, então, uma série de desatualizações do sujeito (linhas 88, 89, 90 e 91) ao reprovar interpretações tendenciosas que os políticos realizam de conversas com o "presidente", o que se configura como um ataque atenuado às faces desses interlocutores.

\section{FRAGMENTO 8}

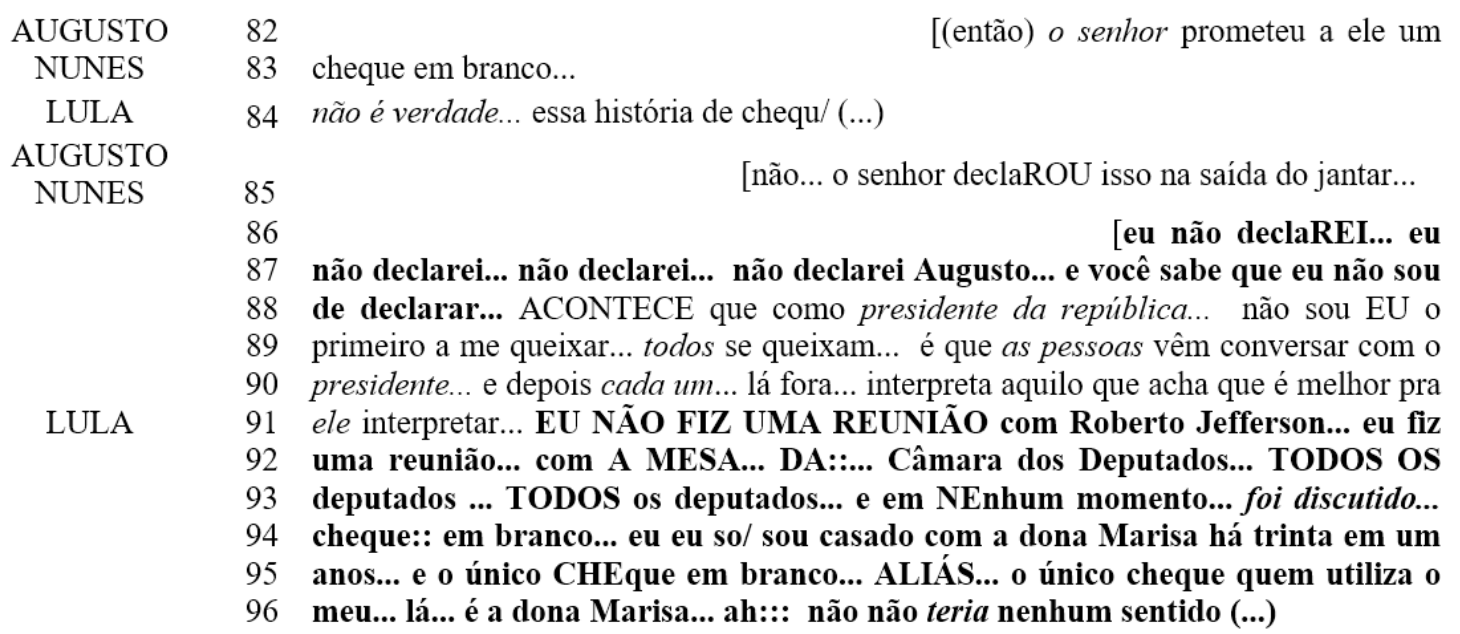

Lula procura, novamente, libertar-se de qualquer vínculo com o deputado Roberto Jefferson (linhas 91-94) e, dessa vez, utiliza a estratégia argumentativa a inclusão da parte no todo em que, conforme Perelman e Olbrechts-Tyteca (2005, p. 262), "o todo engloba a parte e, por conseguinte, é mais importante que ela; em geral, o valor da parte será considerado proporcional à fração que ela constitui com relação ao todo". Como há superioridade do todo sobre suas partes, o entrevistado vincula-se à mesa da Câmara dos Deputados, a todos os deputados, apagando a participação de Roberto Jefferson. Para reforçar a ideia de que nunca ofertaria um cheque em branco, remete à sua vida pessoal referindo-se à relação de confiança que estabelece com sua esposa, única pessoa que utiliza suas folhas de cheque (linhas 94-96). Trata-se de uma ilustração que, de acordo com Perelman e Olbrechts-Tyteca (2005, p. 407), tem a função de "[...] reforçar a adesão a uma regra conhecida e aceita, fornecendo casos particulares que esclarecem o 
enunciado geral, mostram o interesse deste através da variedade das aplicações possíveis, aumentam-lhe a presença na consciência”. Em outras palavras, é o caso particular que serve para fundamentar a regra visando reforçar a credibilidade dos acontecimentos. Em termos de polidez, o emprego da voz passiva (linha 93) e do desatualizador temporal (linha 96), mais uma vez, é explorado.

Posteriormente, a jornalista Roseli Tardelli questiona uma observação de Lula que qualifica os últimos acontecimentos no Congresso de denuncismo vazio. A jornalista pergunta, mitigando seu ato de fala com o uso da partícula hipotética "se" (linha 116), qual seria a razão da queda do ex-ministro José Dirceu, indagação que é atenuada por meio de um desatualizador temporal (linha 118).

\section{FRAGMENTO 9}

\begin{tabular}{|c|c|c|}
\hline ROSELI & 116 & presidente... se é um denuncismo vaZIO::.... e se:: o deputado Roberto Jefferson não \\
\hline \multirow[t]{7}{*}{ TARDELI } & 117 & tem:: razão em nada do que ele falou... POR QUE QUE... o ex-ministro José Dirceu \\
\hline & 118 & acabou caindo? \\
\hline & 119 & eu num tô dizendo que é denuncismo vazio... eu tô dizendo que você tem uma \\
\hline & 120 & mistura de denúncias que são veRÍdicas... e quando se apura você chega à \\
\hline & 121 & conclusão... que elas têm indícios de provas... a::: a::: que que DÃO BASE para uma \\
\hline & 122 & grande investigação::... mas $e u$ estou dizendo que quando se coloca tudo no mesmo \\
\hline & 123 & TAcho... você POde... veja... eu... por exemplo... já afasTEI... quase cinquenta \\
\hline \multirow{7}{*}{ LULA } & 124 & servidores públicos... CERTAMENTE no meio desses... tem gente inocente... \\
\hline & 125 & CERTAMENTE... mas $e u$ fui obrigado a aFAStar porque estavam envolvidos... \\
\hline & 126 & sabe... junto com outras pessoas... no mesmo local de trabalho... \\
\hline & 127 & CERTAMENTE... nós cometemos erros... E EU ACHO que na política... é \\
\hline & 128 & mu::ito difícil você fazer julgamento precipitado e julgar as pessoas... eu ACHO \\
\hline & 129 & que há... uma tentativa de jogar suspeiÇÃo em cima de todo MUNdo... sabe sem \\
\hline & 130 & 」e você TENHA um compromisso de provar... \\
\hline
\end{tabular}

O entrevistado, partindo de um princípio de justiça em que não se pode "colocar tudo no mesmo tacho", faz uso do desatualizador pessoal "você" (linhas 119, 120, 123 e 129), que perde seu valor semântico original e passa a ter a função de pronome indeterminado. Há, mais uma vez, uma variação entre o uso dos pronomes pessoais “eu” (linhas 123, 127 e 128) e "nós” (linha 127), além do emprego de vários outros desatualizadores pessoais, como "gente", "outras pessoas", "as pessoas", "de todo mundo" (linhas 124, 126, 128 e 129). Quando Lula lança mão da estratégia de argumentação de sacrifício ao dizer que foi obrigado a afastar gente inocente (linha 124 e 125) emprega, por exemplo, o pronome pessoal “eu”. Ao usar a expressão "cometer erros" (linha 127), de valor negativo, opta pelo plural "nós".

Em seguida, para apresentar seu ponto de vista sobre como agir no meio político, Lula utiliza o modalizador "eu acho" (linhas $128 \mathrm{e}$ 129) e, apesar de se referir aparentemente à jornalista, talvez tenha como interlocutor alvo os telespectadores, sejam eles políticos ou não. Mais uma vez, há o emprego do fenômeno de polidez negativa tropo comunicacional (linhas 127-130). Ademais, o uso da palavra "suspeição" (linha 129), empregada anteriormente na linha 76, resgata o caso do ex-deputado Roberto Jefferson, que é apresentado como uma espécie de antimodelo, ou seja, "um incentivo a se afastar de certas condutas", conforme Perelman e Olbrechts-Tyteca (2005, p. 417). Talvez, o deputado em questão seja o destinatário principal dessa mensagem.

No trecho seguinte, o titular Augusto Nunes tenta fazer um comentário, mas tem seu turno assaltado pelo entrevistado que dá continuidade ao processo argumentativo precedente empregando, mais uma vez, o modalizador "eu acho" (linhas 132 e 136) e alguns desatualizadores pessoais (linhas 138 e 139). 
FRAGMENTO 10

\begin{tabular}{|c|c|c|}
\hline & 131 & mas presidente(...) \\
\hline AUGUSTO N. & 132 & $\boldsymbol{E U} \boldsymbol{A C H O} . .$. portanto $\boldsymbol{e} \boldsymbol{u} \boldsymbol{A C H O} \ldots$ que o papel da CPI:.... neste instante... é o de \\
\hline \multirow{8}{*}{ LULA } & 133 & apurar... a CPI tá instaLADA... têm três CPIs... elas têm que investigar:.... depois \\
\hline & 134 & disso vai cair na mão do Ministério Público... que vai investiGAR... se preciSAR a \\
\hline & 135 & Polícia Federal investiGAR... vai investiGAR... depois disso vai cair na mão do \\
\hline & 136 & Supremo Tribunal Federal que vai julgar... É ASSIM que que funciona... EU Só \\
\hline & 137 & $A C H O$ que as denúncias devem ser feitas quando tiver prova... se não tiver \\
\hline & 138 & prova... por favor... SAbe... peça pra polícia investigar antes de denunciar... \\
\hline & 139 & porque... senão... você pode exeCRAr a VIda de uma pessoa::... sabe... e depois \\
\hline & 140 & provar que é inocente e não recuperar mais esse crédito \\
\hline
\end{tabular}

Em seguida, o tropo comunicacional é explorado novamente e Lula apresenta o que seria um modelo, ou seja, o oposto ao antimodelo, a conduta que se deve seguir (linhas 137 e 138) no meio político, ao dizer que denúncias só devem ser feitas quando houver provas. Conforme detalham Perelman e Olbrechts-Tyteca (2005, p. 413), “[...] quando se trata de conduta, um comportamento particular pode não só servir para fundamentar ou ilustrar uma regra geral, como para estimular uma ação nele inspirada”. A partir da apresentação de um argumento pragmático, Lula dirige, indiretamente, uma crítica a Roberto Jefferson (linhas 139 e 140) enfocando as consequências nocivas de seus atos. Mesmo assim, utiliza a fórmula de polidez "por favor" para atenuar sua crítica.

No próximo fragmento, Lula responde a uma pergunta sobre José Dirceu, "Zé Dirceu” para Lula, o que denota proximidade entre ambos, realizada, anteriormente, por Roseli Tardelli. O entrevistado relata em discurso direto uma conversa com José Dirceu, em que o convence a continuar como ministro chefe da Casa Civil. Para tanto, emprega a estratégia de argumentação vínculo causal mostrando ao ministro que não há motivo para deixar seu cargo, uma vez que quem está sendo atacado é Waldomiro, com o qual Dirceu afirma não ter nenhuma relação. Logo em seguida, estabelece outro vínculo causal afirmando que se for tirar cada um que é denunciado, não é possível montar um governo (linhas 149-151).

\section{FRAGMENTO 11}

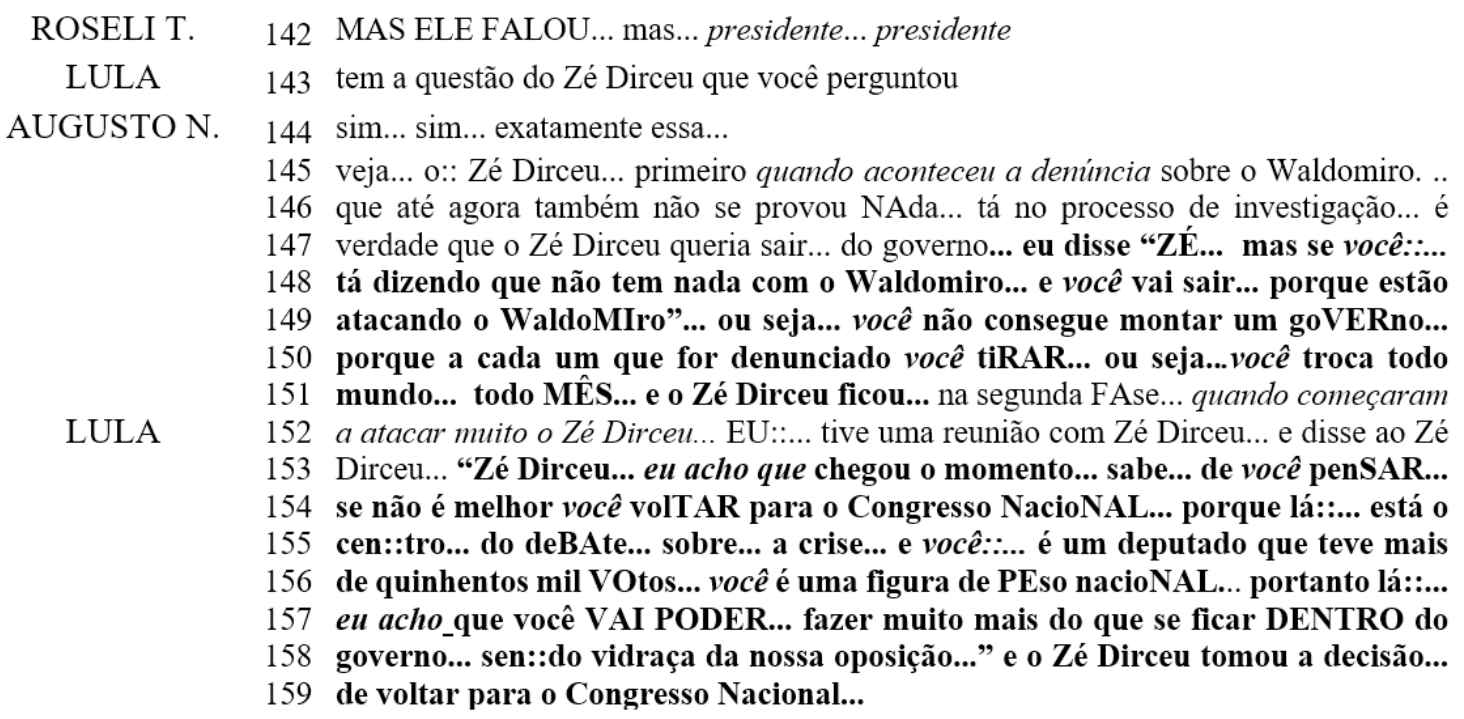


Ao se referir à segunda fase, mais um vínculo causal, introduzido pelo modalizador "eu acho" (linha 153), é estabelecido para convencer Dirceu: "eu acho que chegou o momento de você pensar se não é melhor você voltar para o Congresso Nacional, porque lá está o centro de debate sobre a crise" (linhas 153-155). Lula também faz uso do recurso a interação entre o ato e a pessoa (linhas 155-157) ao ressaltar o peso da figura do político no país e, finalmente, conclui empregando um argumento pragmático (linhas 157 159) introduzido pelo modalizador "eu acho" (linha 157), ao se referir às consequências do retorno de Dirceu ao Congresso Nacional que, dentro do governo, "estava sendo vidraça da nossa oposição" (linha 158). Como podemos notar, Lula reforça o seu argumento por meio do uso de uma metáfora que, na tradição da retórica, conforme Perelman e Olbrechts-Tyteca (2005, p. 453), trata-se de um tropo, ou seja, de “[...] uma mudança bem-sucedida de significação de uma palavra ou de uma locução". Assim, "vidraça” acaba assumindo um outro significado, o de "alvo", por exemplo.

Acreditamos relevante observar, nesse excerto, as construções introdutórias às duas etapas de argumentação desenvolvidas por Lula, a saber, "quando aconteceu a denúncia" e "começaram a atacar muito o Zé Dirceu”, ambas com sujeitos desatualizados. Outro ponto importante diz respeito ao emprego do pronome sujeito "você", que se alterna entre a função de pronome de tratamento informal e um sentido impessoal por meio de um ato de generalização do sujeito.

Na passagem seguinte, quando o titular Augusto Nunes afirma que José Dirceu está em uma defensiva que o levará à cassação, o faz empregando o atenuador "só" (linha 162), que cumpre o papel de minimizador. Lula, por sua vez, suspira e utiliza repetidamente a expressão "eu não sei" e afirma desconhecer a tática ou estratégia escolhida por Dirceu. Porém, valoriza a face do ministro empregando a estratégia argumentativa interação entre o ato e a pessoa, além de apresentá-lo como político "modelo", modo de proteger o grupo e seus membros (linhas 167-170) e emprega, mais uma vez, o modalizador "eu acho" (linha 167) para introduzir uma avaliação mais suavizada.

\section{FRAGMENTO 12}

\begin{tabular}{|c|c|c|}
\hline \multirow[b]{2}{*}{ AUGUSTO N. } & 162 & só tá se \\
\hline & $\begin{array}{l}163 \\
164\end{array}$ & $\begin{array}{l}\text { defendendo... presidente... desde que ele voltou... ele não fez um aTAque... tá numa } \\
\text { defensi::va... que deveRÁ levá-lo à cassação (...) }\end{array}$ \\
\hline \multirow{6}{*}{ LULA } & 165 & {$[(($ suspiro $))$ eu não sei... eu não sei... eu não sei... qual é a } \\
\hline & 166 & TÁtica... ou qual é a estratégia... esse negócio de tática e de estratégia... sempre me \\
\hline & 167 & confunde... mas de qualquer forma... eu acho que o Zé Dirceu TEM... experiência \\
\hline & 168 & política... porque feliz do pa::ís... que tem um político... da magnitude do Zé \\
\hline & 169 & Dirceu... TEM coragem... e inteliGÊ Ncia... pra fazer o enfrentamento... se ele \\
\hline & 170 & tabeleceu que a tática neste momento é $\operatorname{ESSA}(\ldots)$ \\
\hline
\end{tabular}

A ideia de pertencimento ao grupo que encerrou o enunciado anterior é retomada no próximo fragmento pelo entrevistador que, provavelmente, ciente do impacto que sua pergunta poderia causar, utiliza os pronomes de tratamento "senhor", "presidente" e um desatualizador verbal (linha 172) para mitigá-la. O entrevistado a responde com firmeza, atualizando o tempo verbal da resposta para o presente dizendo "eu sou" (linha 173), assumindo, assim, todas as responsabilidades e riscos decorrentes de seu ato. Em seguida, para se defender, inverte os papéis, passa de entrevistado a entrevistador, o que se configura como um ataque à face do titular, pois, além de ter sido diretamente interpelado, houve uma quebra de regras relativas aos papéis interacionais (linhas 173175). 


\section{FRAGMENTO 13}

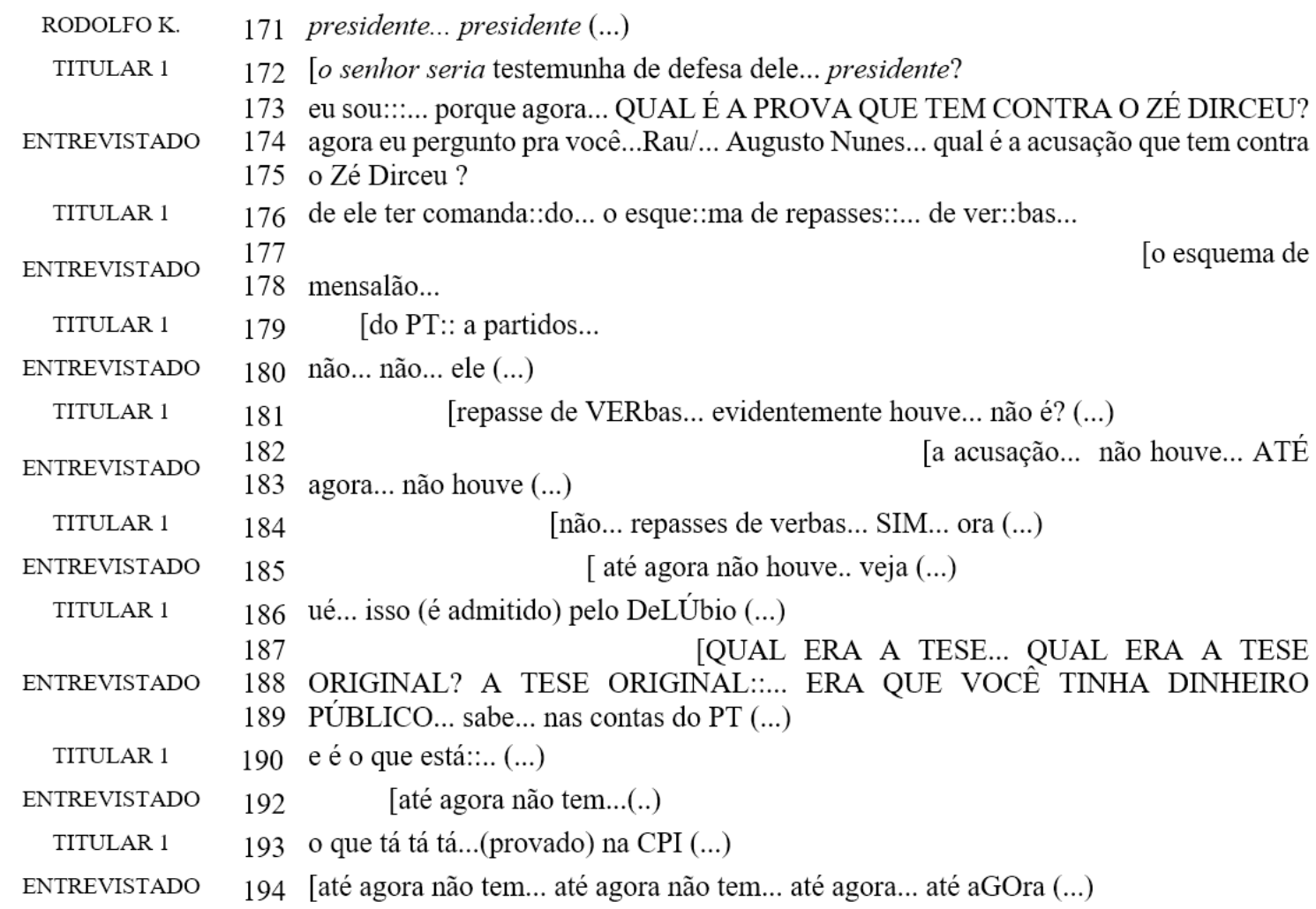

Esse momento transforma-se, então, no propulsor de uma série de turnos de fala em que não houve nenhuma ocorrência de estratégias de argumentação e, concomitantemente, de mecanismos de polidez verbal. O que ocorre é um intenso assalto de turnos da fala e a apresentação de uma série de denúncias contra o PT que são imediatamente e intensamente refutadas e negadas por Lula (linhas 176-194). Se observarmos as variações prosódicas que se apresentam ao longo dessa passagem, sobretudo na fala do entrevistado, podemos notar que há um certo embate entre os interactantes. Não se trata, no entanto, de uma manifestação de "impolidez", mas de uma "não-polidez" ou "apolidez", conforme define Kerbrat-Orecchioni (2014, p. 53), "[...] ausência "normal" de qualquer marcador de polidez acompanhando um FTA”. Essa troca conversacional mais abrasada somente tem fim quando o jornalista Rodolfo Konder tenta fazer uma pergunta.

O último fragmento do corpus analisado configura-se como o desfecho da troca comunicacional precedente. Podemos observar que há ainda uma variação prosódica marcante nas falas dos interlocutores, sobretudo nas do entrevistado, o que pode ser um indício de uma certa inquietação. Nesse sentido, os raros mecanismos de polidez verbal presentes nesse excerto foram empregados pelos entrevistadores. Inicialmente, o titular Auguto Nunes declara que "essa história do Banco do Brasil 'pode ser' o fio da meada" (linhas 196 e 197), estratégia que encontra eco na resposta do entrevistado "pode ser'... vamos esperar para ver se é” (linhas 198 e 199), o que confere ao enunciado um teor menos peremptório por expressar uma ideia de dúvida. 


\section{FRAGMENTO 14}

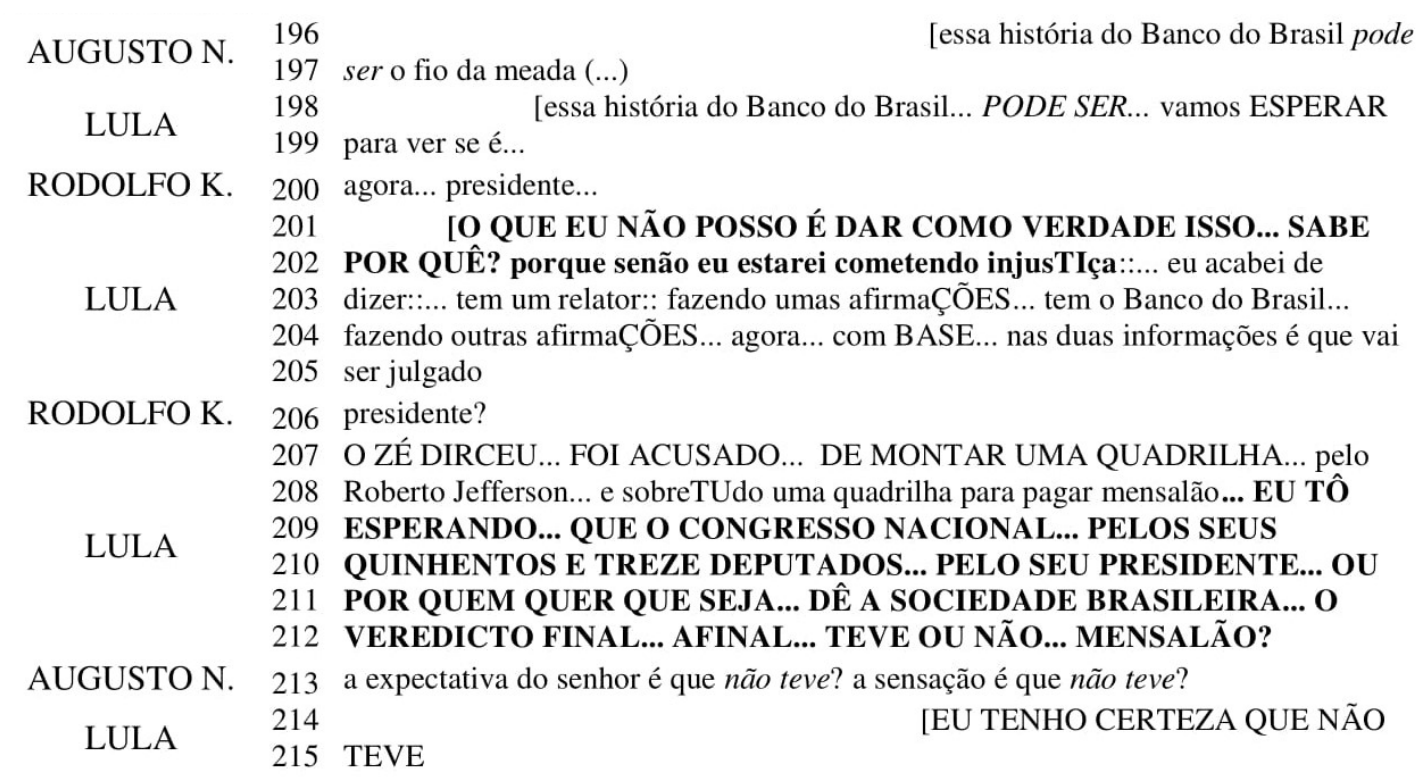

Posteriormente, o entrevistado, de acordo com suas palavras, por uma questão de justiça, afirma não poder "dar isso [o mensalão] como verdade", desenvolvendo um processo de argumentação pelo intermédio da estratégia vínculo causal (linhas 201 e 202). Lula mantém seu turno e, mais uma vez, faz uso da tática de argumentação o grupo e seus membros, ou seja, o grupo de políticos, formado pelos seus quinhentos e treze deputados, além de seu presidente, seria responsável por responder à sociedade se houve ou não mensalão. Dessa forma, o entrevistado não se coloca no papel de agente, mas de espectador, como toda a sociedade brasileira. Nesse momento, ocorre uma espécie de desvinculação de Lula do grupo político e uma vinculação à sociedade.

Por fim, o entrevistador titular coloca a última pergunta do presente corpus, atenuada pelo uso da forma negativa "não teve" (linha 213), ao então presidente indagando-o sobre qual seria sua "expectativa" sobre o mensalão, termo substituído logo em seguida por "sensação". Sobrepõe, assim, uma avaliação mais emocional ou intuitiva a uma de natureza mais concreta, talvez para conquistar a adesão de seu interlocutor à pergunta, o qual responde firmemente que tem certeza que não houve mensalão. Aqui, Lula vincula-se novamente a seu partido e o defende com veemência.

Essa é a única troca comunicativa em que não há o uso integrado de estratégias de argumentação com mecanismos de polidez. Isso talvez tenha ocorrido pelo fato de que o maior detentor dos turnos de fala nesse fragmento tenha sido o entrevistado que, no momento, apresentava um discurso mais contundente.

\section{CONSIDERAÇÕES FINAIS}

O presente trabalho teve por objetivo examinar o emprego de estratégias de argumentação em conjunto com os mecanismos de polidez verbal em uma entrevista televisiva com o ex- presidente da República Luiz Antônio Lula da Silva, enquanto seu governo enfrentava uma das maiores crises da política nacional, conhecida como mensalão. Dessa forma, esta análise se propôs a apontar algumas perspectivas acerca do uso de estratégias de argumentação e de polidez verbal em um contexto específico de realização. Nossa intenção era delinear alguns apontamentos que possam contribuir para futuros estudos.

Em relação ao uso de estratégias de argumentação, foi possível observar que essas táticas estiveram presentes praticamente no decorrer de toda a entrevista. Houve ocorrências de argumentos quase-lógicos, argumentos baseados na estrutura do real e ligações que fundamentam a estrutura do real. Os argumentos baseados na estrutura do real foram os mais requisitados e, segundo nossa avaliação, não houve ocorrência de dissociações das noções. A totalidade de estratégias de argumentação presentes no corpus foi 
empregada pelo entrevistado, talvez pelo fato de ser o principal detentor dos turnos de fala, o que não foge aos objetivos do gênero oral entrevista, a saber, escutar um convidado que responde a perguntas e tenta convencer seus interlocutores da pertinência de suas ideias.

Por outro lado, no tocante às estratégias de polidez, pode-se notar um certo equilíbrio em relação ao seu uso, uma vez que entrevistadores e entrevistado lançam mão desses mecanismos em suas intervenções. Como se trata de uma entrevista jornalística, ou seja, que visa à informação e o debate de ideias, as únicas ocorrências de FFTs apresentaram-se na abertura da entrevista e resumiram-se a saudações e agradecimentos. Todavia, houve inúmeras ocorrências de estratégias de polidez negativa que atenuaram os FTAs que se produziram no decorrer da interação, tanto de caráter substitutivo, quanto de caráter subsidiário. Além desses procedimentos repertoriados por Kebrat-Orecchioni (2005), foram encontradas no corpus ocorrências de perguntas construídas na forma negativa, o que talvez possa se configurar como estratégia de polidez negativa.

Julgamos pertinente destacar que há um processo de decrescimento em relação ao emprego de estratégias de polidez conforme a entrevista avança, ou seja, há uma maior preocupação de preservação de faces no início da interação do que no encerramento do excerto, marcado por um clima mais veemente e conflituoso. Contudo, apesar desse ambiente de divergência de opiniões, não houve ocorrências de impolidez, mas de não-polidez, a saber, a ausência "normal" de qualquer marcador de polidez. Nessa circunstância, também ocorreu o desaparecimento das estratégias de argumentação que, via de regra, estavam sempre acompanhadas de mecanismos de polidez, como se a integração dessas duas estratégias discursivas abrisse caminho para uma interação efetiva que, independentemente dos percalços que podem se apresentar durante o seu desenvolvimento, cumpre, concomitantemente, com seu papel comunicativo e social, uma vez que não há quebra do processo interacional que continua a evoluir naturalmente, tanto que, no momento em que as estratégias de argumentação e de polidez verbal desaparecem, a comunicação torna-se ineficiente, repleta de assaltos ao turno e de enunciados entrecortados.

Os turnos de fala finais da entrevista representam o único instante em que há o uso de estratégias de argumentação desacompanhadas de estratégias de polidez verbal. Certamente, o discurso cumpre com seu papel informativo, mas talvez não ocorra o mesmo com o seu papel social, uma vez que a fala do principal e quase exclusivo detentor do turno, a saber, o entrevistado, está marcada por uma entoação enfática, o que pode ser sinal de uma certa inquietação e se configurar como um ataque às faces dos envolvidos na interação.

\section{REFERENCIAS}

ARISTÓTELES. Retórica. Introdução de Manuel Alexandre Junior. Tradução do grego e notas de Manuel Alexandre Junior, Paulo Farmhouse Alberto e Abel do Nascimento Pena. 2. ed.Lisboa: INCM, 1998.

BRETON, Ph.; GAUTHIER, G. História das teorias da argumentação. Tradução de Maria Carvalho. Lisboa: Editorial Bisâncio, 2001.

BROWN, P.; LEVINSON, S. Politeness. Some universals in Language usage. Cambridge: Cambridge University Press, 1987 [1978]. 
GOFFMAN, E. Frame analysis. New York: Harper \& Row, 1974.

KERBRAT-ORECCHIONI, C. Polidez e Impolidez nos debates políticos televisivos: o caso dos debates entre dois turnos dos presidentes franceses. In: SEARA, Isabel R. Cortesia: olhares e (re)invenções. Lisboa: Chiado Editora, p. 47-82, 2014.

. Análise da conversação: princípios e métodos. Tradução de Carlos Piovezani Filho. São Paulo: Parábola Editorial, 2005.

LAKOFF, R. Langage and woman's Place. New York: Harper \& Row, 1975.

LEECH, G.N. Principles of pragmatics. London: Longman, 1983.

MAINGUENEAU, D. Termos-chave da análise do discurso. Belo Horizonte: UFMG, 1998.

PERELMAN, Ch; OLBRECHTS-TYTECA, D. Tratado da argumentação: a nova retórica. Tradução de Maria Ermantina Galvão. 2. ed. São Paulo: Martins Fontes, 2005.

PLANTIN, Ch. A argumentação biface. In: LARA, Gláucia M. P.; MACHADO, Lucia; EMEDIATO, Wander (Org.). Análise do discurso hoje. v. 2. Rio de Janeiro: Nova Fronteira, 2009. p. 14-29.

SILVA, L. I. L. da. Entrevista [2005]. Entrevistadores: P. Marcun, A. Nunes, H. Barbeiro, R. Tardeli e R. Konder. Brasília: Palácio do Planalto, 2005. Entrevista concedida ao programa Roda Viva da TV Cultura. Disponível em: $<$ https://www.youtube.com/watch?v=6S5krf8c5mE> Acesso em: 7 nov. 2016. 